\title{
Influence of Community Characteristics on Improving Welfare Through Tourism Development
}

\author{
$1^{\text {st }}$ Neli Aida ${ }^{1}$ \\ \{Neliaida422@gmail.com $\left.{ }^{1}\right\}$ \\ Universitas Lampung, Indonesia ${ }^{1}$
}

\begin{abstract}
Community characteristics have a large impact on the development of tourism and welfare improving. Head of household is an important aspect of developing tourism and poverty alleviation. The average assets, health, and education of household members are assets for tourism development, but household size, dependency ratio, and employment opportunities also have an important influence on development.This study aims to determine the effect of community characteristics on tourism development and their impact on improving welfare in Kiluan Village with a quantitative descriptive analysis. The results community characteristics has a direct effect on tourism development, community Characteristics has direct influence on improving welfare, and Characteristics of community has an indirect effect on improving welfare through tourism development. The implications of this research can be used as a basic consideration for local goverments or private sectors for tourism development and improving welfare levels in the end.
\end{abstract}

Keywords: tourism development, community characteristic, welfare.

\section{INTRODUCTION}

Development in Indonesia aims at the welfare of its people, including the Tanggamus Regency which is focused on increasing the number of prosperous and poor families. In line with this problem, Tanggamus Regency has the potential wealth and diversity of coastal and biological ecosystems as resources that must be utilized and as engines of growth [1]. Study of the development of tourism-based economic changes in Indonesia (case the village) can be seen from community characteristics, community characteristics are mutual distrust interpersonal relations, perceived limited good, dependence on hostility towards government authority, familism, lack of innovations, fatalism, limited aspiration, lack of deferred gratification, limited view this world, low emphaty [2].

The Australian Department of Tourism in [3] which defines "tourism is nature-based tourism by including aspects of education and interpretation of the natural environment and culture of the community with ecological conservation. According to the [4] in welfare resolution is the most fundamental choices and opportunities for human development to live a long and creative life, and enjoy a decent standard of freedom of life, dignity and respect from others.

Table 1. Main Determinant Of Community Characteristics

\begin{tabular}{|l|l|}
\hline Variable & \multicolumn{1}{|c|}{ Indicator } \\
\hline & $\begin{array}{l}\text { Mutualdistrustinterpersonal } \\
\text { relations } \\
\text { Families }\end{array}$ \\
\hline
\end{tabular}




\begin{tabular}{|l|l|}
\hline Community Characteristics & Lack of innovations \\
& Fatalism \\
& Limited aspiration \\
& Lack of deferred gratification \\
& Limited view this world \\
& Low empathy \\
\hline
\end{tabular}

Source: World Bank (2009) and Aida. N., (2019)

[2] explained that to improve welfare, people will be free from poverty and enjoy a better life. Strong confidence, a distant perspective, avoiding dependence, strong kinship, and accepting innovation.

This problem is also faced by the Tanggamus Regency Government, especially in Kiluan Village as the place of this research. The community has a low educational background, and farmers are the livelihoods of the people. The description described above, interested researchers review how the characteristics of the community can develop Tourism and have implications for welfare in Kiluan Village, Tanggamus Regency, Lampung Province. The formulation of the problem is: What is the effect of community characteristics on improving welfare through the development of tourism in Kiluan Village?

\section{LITERATURE REVIEW}

1. Characteristics of the Community $(\mathrm{X})$

World Bank (2009) and Aida, N (2019) to calculate the Characteristics of the community (X), there are eight (8) sub-variables, namely: are mutual distrust interpersonal relations authority (X1), familism (X2), lack of innovation (X3), fatalism (X4), limited aspiration (X5), lack of deferred gratification (X6), limited view of this world (X7), low empathy (X8)

2. Tourism Development (Z)

[5] to calculate it, there are three indicators, such as: 1. Economic Benefits (Z1) 2. Tourism Attractions (Z2) 3. Infrastructure (Z3)

3. Welfare $(\mathrm{Y})$

[6] and [7] calculate the value of Welfare in Kiluan Village, which is seen from one

(2) sub-variables, namely: Income (Y1), and Health (Y2)

4. Chart Track Testing Model

Based on the explanation of each construct variable measurement model (Characteristics of the community, Tourism Development, and welfare that have been explained previously, it can be shown and explained the overall path diagram form model, as follows: 


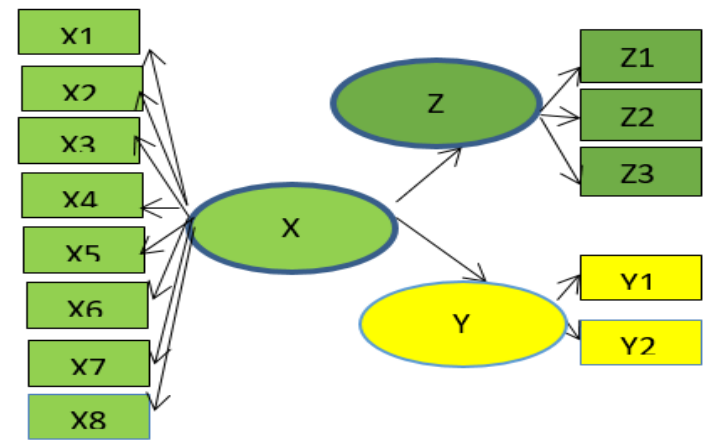

Figure 1 Part Chart Testing Model

Sources: Research Result

Characteristics of community have a significant positive effect on improvement welfare through tourism development. In the Literature Review, also describe the development of research hypotheses, that is community characteristics have a significant positive effect on tourism development. The characteristics of community have a significant positive effect on improvement welfare through tourism development. .

\section{METHODOLOGIES AND DATA ANALYSIS}

This research was analyzed descriptively quantitatively by survey method [8]. Qualitative information was captured through informants, using a list of questions, then using Smart PLS version 2.0 calculated [6] and [9]. Location of the study in Kiluan Village, Kelumbayan District, Tanggamus Regency, Lampung Province. A total sample of 126 households was validated.

\section{RESEARCH RESULT AND DISCUSSION}

This research can be constructed path diagram using Smart PLS software version 2.0; the path diagram can be described as follows:

1. Result

$\mathrm{X} \rightarrow \mathrm{Z}$ : Community characteristics have a significant positive effect on tourism development, by increasing community characteristics will improve tourism development.

$\mathrm{X} \rightarrow \mathrm{Y}$ : The characteristics of community have a significant positive effect on improvement welfare, by increasing community characteristics will increase improvement welfare.

$\mathrm{X} \rightarrow \mathrm{Z} \rightarrow \mathrm{Y}$ : Characteristics of community have a significant positive effect on improvement welfare through tourism development, by increasing community characteristics will increase improvement welfare through tourism development. 


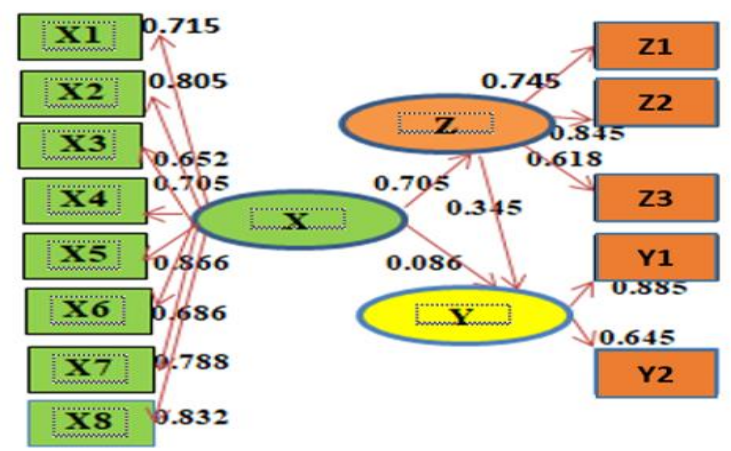

\subsection{Hypothesis examining}

Source: Research Result, 2019

\section{Hypothesis 1:}

Community Characteristics (X) has a significant effect on Tourism Development $(\mathrm{Z})$ with a path coefficient of 0.705 and a calculated $t$ value of 13.333 (> 1.96) significance of $0.000(<0.05)$, means Community Characteristics (X ) has a direct effect on tourism development (Z).

Hypothesis 2:

Community Characteristics (X) has a significant effect on improvement welfare (Y) with path coefficient values of 0.086 and $t$ count values of 2.320 (> 1.96) significance $0.021 \quad(<0.05)$, means Community Characteristics $(X)$ direct influence on improvement welfare (Y). Hypothesis 3:

Community Characteristics $(\mathrm{X})$ has a significant effect on improvement welfare through tourism development. (Y) through Tourism Development (Z) with path coefficient value of 0.345 and $t$ count value of 11.453 (> 1.96) significance of $0.000(<0.05)$, means Characteristics Community $(X)$ has an indirect effect on improvement welfare (Y) Through Tourism Development (Z).

\subsection{Discussion}

By empowering community characteristics, existing work is absorbed in tourism management. As in the field of work, the absorption of women to work helps their husbands create added value for household needs that will have an impact on economic change for the better. For example: by renting houses, boats, tires and mats to visitors or selling agricultural products such as corn, durian and other fruits, as well as seafood in the form of fish, it creates more value for the people's economy. The development of tourism villages requires an active role in the community. This study also uses indicators of community characteristics (Fei, L., et.al 2018), similar to Aida's research. The size of the household is not a burden, it is the obligation of parents to meet the needs of their families as well as the dependency ratio. Gender Contribution Household heads are seen in women's involvement in helping meet their needs. The assets owned by the Kiluan community are private gardens or rice fields, which are inherited from generation to generation. The average occupation of the Kiluan community is as a farmer with an average income of $\leq 1.5$ million per month. 
Therefore, the Tanggamus Regency government has conducted a women's empowerment program through bamboo weaving crafts. Most household members are aware of health and education. All of these activities are carried out with mutual trust in the bond of interpersonal relationships, kinship even though within the limitations of innovation, aspirations, appearance and empathy.

Management of tourism by empowering the people of Kiluan. This means that the role of community characteristics is very influential on improving welfare through tourism development. The existence of tourism can help household expenses to meet the needs of life. The economic benefits of an area, with tourism, will open business opportunities and income for the village, such as stalls, entrance tickets, tire rental, rental of mats, and sale of agricultural products or sea catches. Planning and controlling, development plans will be carried out in the tourism area to accommodate more visitors.

\section{SUMMARY}

Socially, togetherness to promote tourism. Even now, there are increasing attractions: the camping arena, locations for photos, limited infrastructure available in this area; cellphone signal towers are not yet available, lodging, ATMs, health centers, monitoring towers, and bridges. Poverty, in terms of income, is still below the Regional Minimum Wage (UMR) of Kiluan Regency. Economically, tourism has helped an active role in reducing the poverty of the Kiluan people in a sustainable manner.

\section{IMPLICATIONS / LIMITATIONS AND SUGGESTIONS FOR FURTHER RESEARCH}

The Kiluan community is aware of tourism assets, which are very beneficial to various groups, and this has caught the attention of the government. Infrastructure is the main aspect of tourism sustainability to support visitor safety and comfort. The District Government of Kiluan, together with the people of Kiluan, builds and improves various infrastructures needed by tourism.

\section{REFERENCE}

[1] W. Chulaphan and J. F. Barahona, "Kasetsart Journal of Social Sciences Contribution of disaggregated tourism on Thailand 's economic growth," Kasetsart J. Soc. Sci., pp. 1-6, 2017, doi: 10.1016/j.kjss.2017.07.012.

[2] N. Aida, A. Suman, and R. K. Sakti, "Economic and Non-Economic Implications of Community Based Tourism ( CBT ) Supply Chain at Around Teluk Kiluan Beach Tanggamus Regency Lampung Province of Indonesia,” vol. 8, no. 4, pp. 191-198, 2019.

[3] Y. Lee and G. Hsieh, "Does Slacktivism Hurt Activism ?: The Effects of Moral Balancing and Consistency in Online Activism," no. July 2016, 2013, doi: 10.1145/2470654.2470770.

[4] "No Title."

[5] T. Gugushvili, G. Salukvadze, and J. Salukvadze, "Fragmented Development : Tourism-driven Economic Changes in Kazbegi ," Ann. Agrar. Sci., no. February, 2017, doi: 10.1016/j.aasci.2017.02.005.

[6] C. Palacios, D. Student, and L. Caneday, "On the key elements for successful management and development of community-based tourism ventures in rural areas," 
2016.

[7] A. Kusumawanto and D. Kristiadi, "Skema inovatif pemenuhan kesejahteraan atas papan," vol. 6, no. 1, pp. 47-61, 2016.

[8] M. Sarstedt, "The Great Facilitator Re fl ections on the Contributions of," no. May, 2019, doi: 10.1007/978-3-030-06031-2.

[9] E. Kastenholz, M. J. Carneiro, C. P. Marques, S. Maria, and C. Loureiro, "The dimensions of rural tourism experience : impacts on arousal , memory, and satisfaction The dimensions of rural tourism experience : impacts on arousal, memory , and satisfaction," J. Travel Tour. Mark., vol. 00, no. 00, pp. 1-13, 2017, doi: 10.1080/10548408.2017.1350617. 